\title{
Doppler Rayleigh/Mie/Raman lidar for wind and temperature measurements in the middle atmosphere up to $80 \mathrm{~km}$
}

\author{
G. Baumgarten \\ Leibniz-Institute of Atmospheric Physics at the Rostock University, 18225 Kühlungsborn, Germany
}

Received: 4 May 2010 - Published in Atmos. Meas. Tech. Discuss.: 1 July 2010

Revised: 27 October 2010 - Accepted: 28 October 2010 - Published: 4 November 2010

\begin{abstract}
A direct detection Doppler lidar for measuring wind speed in the middle atmosphere up to $80 \mathrm{~km}$ with $2 \mathrm{~h}$ resolution was implemented in the ALOMAR Rayleigh/Mie/Raman lidar $\left(69^{\circ} \mathrm{N}, 16^{\circ} \mathrm{E}\right)$. The random error of the line of sight wind is about $0.6 \mathrm{~m} / \mathrm{s}$ and $10 \mathrm{~m} / \mathrm{s}$ at $49 \mathrm{~km}$ and $80 \mathrm{~km}$, respectively. We use a Doppler Rayleigh Iodine Spectrometer (DoRIS) at the iodine line $1109(\sim 532.260 \mathrm{~nm})$. DoRIS uses two branches of intensity cascaded channels to cover the dynamic range from 10 to $100 \mathrm{~km}$ altitude. The wind detection system was designed to extend the existing multi-wavelength observations of aerosol and temperature performed at wavelengths of $355 \mathrm{~nm}, 532 \mathrm{~nm}$ and $1064 \mathrm{~nm}$. The lidar uses two lasers with a mean power of $14 \mathrm{~W}$ at $532 \mathrm{~nm}$ each and two $1.8 \mathrm{~m}$ diameter tiltable telescopes. Below about $49 \mathrm{~km}$ altitude the accuracy and time resolution is limited by the maximum count rate of the detectors used and not by the number of photons available. We report about the first simultaneous Rayleigh temperature and wind measurements by lidar in the stratoand mesosphere on 17 and 23 January 2009.
\end{abstract}

\section{Introduction}

Wind measurements are essential for understanding the dynamics in the middle atmosphere on small $(<100 \mathrm{~km})$ to global scales. Lidar measurements in the altitude range from $15 \mathrm{~km}$ to $70 \mathrm{~km}$ are needed (Meriwether and Gerrard, 2004) as there is no other remote sensing method capable to study the time/altitude cross section of temperatures and winds in the so-called radar gap (Fig. 1). Although the basic concepts for lidar wind measurements were introduced and applied about two decades ago, the technical realization is challenging (e.g., Chanin et al., 1989; Rees and McDermid, 1990; Tepley et al., 1991). Several methods for lidar wind measurements to altitudes above $15 \mathrm{~km}$ have been proposed and partly demonstrated (e.g., Abreu et al., 1992; Tepley et al., 1993; Garnier and Chanin, 1992; Gentry et al., 2000) Besides limited experiments demonstrating that the method is feasible, there are up to now only a few reports of regular wind measurements to about $50 \mathrm{~km}$ altitude by Rayleigh lidar (Tepley, 1994; Rees et al., 1996; Friedman et al., 1997; Souprayen et al., 1999).

At the ALOMAR research station in Northern Norway a comprehensive set of instruments is used to study atmospheric dynamics. Meteorological rockets and radiosondes have been used to study the wind profile in a large number of case studies (e.g., Goldberg et al., 2004; Müllemann and Lübken, 2005). Radar observations covering the altitude ranges of $1-15 \mathrm{~km}$ and about $60-110 \mathrm{~km}$ are continuously available from the MST radar, MF radar or SKiYMET meteor radar (Latteck et al., 1999; Singer et al., 1997, 2003). At the altitude of about $80-105 \mathrm{~km}$ measurements with a sodium lidar are performed (Williams et al., 2004). To fill the gap between the radar wind measurements from about $15 \mathrm{~km}$ to above $60 \mathrm{~km}$ a Doppler Rayleigh wind lidar was developed and installed. Our realization of a Doppler wind lidar is part of a system designed for simultaneous and routine soundings of aerosol, temperature and wind in the middle atmosphere with high stability. Up to now no simultaneous temperature and wind measurements by Rayleigh lidar above $50 \mathrm{~km}$ have been published (Huang et al., 2009). Here we present the first simultaneous temperature and wind measurements by Rayleigh lidar up to $80 \mathrm{~km}$.

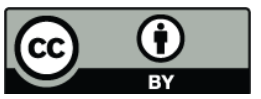

Correspondence to: G. Baumgarten

(baumgarten@iap-kborn.de)

Published by Copernicus Publications on behalf of the European Geosciences Union. 


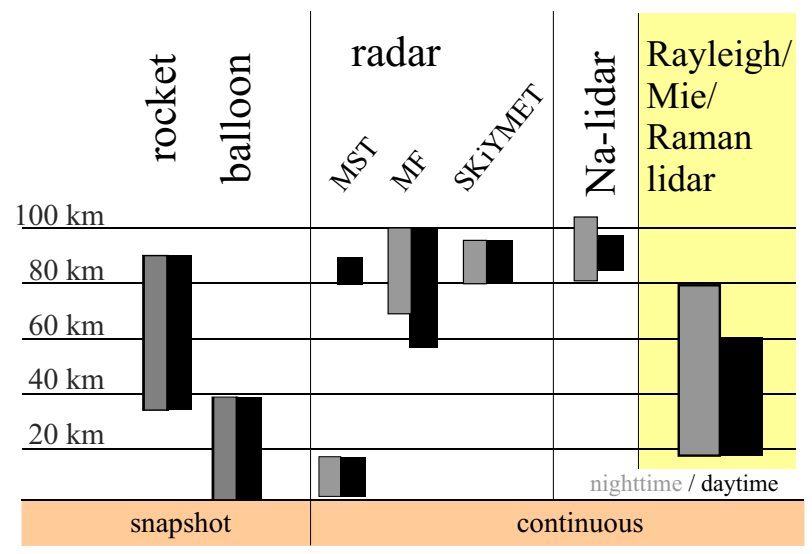

Fig. 1. Altitude range of different methods for sounding wind at the ALOMAR research station in Northern Norway.

\section{Method and instrumental setup}

Wind measurements with the Rayleigh/Mie/Raman lidar at the ALOMAR research station in Northern Norway $\left(69.3^{\circ} \mathrm{N}\right.$, $16.0^{\circ} \mathrm{E}$ ) are performed by direct detection of the Doppler shift. The lidar is in routine operation since 1994 and is among others used for long-term monitoring of the middle atmosphere (von Zahn et al., 2000). For example an extensive dataset of observation of noctilucent clouds (NLC) and their particle properties has been accumulated (Fiedler et al., 2009; Baumgarten and Fiedler, 2008). The design and integration of the Doppler wind capability was performed in a way that the time series of observations was not interrupted. We have developed a single photon spectrometer analyzing the Doppler shift of the Cabannes line using iodine absorption spectroscopy at line 1109 (Young, 1981; She et al., 2007; Gerstenkorn and Luc, 1978). The Cabannes line and the iodine absorption spectrum are shown in Fig. 2. A similar technique was successfully applied to a tropospheric lidar system (Liu et al., 1997, 2002, 2007). The Doppler shift for $1 \mathrm{~m} / \mathrm{s}$ wind speed is about $4 \mathrm{MHz}(\Delta \lambda \sim 4 \mathrm{pm})$ at a wavelength of $\lambda=532.260 \mathrm{~nm}$ or $\Delta \lambda / \lambda \sim 10^{-8}$. The Doppler Rayleigh Iodine Spectrometer (DoRIS) achieves a wavelength precision of $\Delta \lambda / \lambda \sim 10^{-8}$ by measuring a signal ratio with a precision of $S_{\mathrm{I}_{2}} / S_{0} \sim 10^{-3}$. Here $S_{0}$ and $S_{\mathrm{I}_{2}}$ are the signals before and behind the $\mathrm{I}_{2}$ cell, respectively. In order to measure the horizontal wind vector, we use two independently tiltable telescopes (diameter $1.8 \mathrm{~m}$ ) and two lasers to measure both components of the horizontal wind, projected on the line of sight of the telescopes. The technical realization is depicted in Fig. 3. Light from the two power lasers is guided to the top of the telescopes and emitted coaxially to the optical axis of the receiving telescopes. The two power lasers are both seeded by one single cw-laser. To achieve a high stability of the seed laser it is in continuous operation and stabilized by iodine absorption spectroscopy to the slope of $\mathrm{I}_{2}$-line 1109 . The seed wavelength was chosen to optimize the wind re-

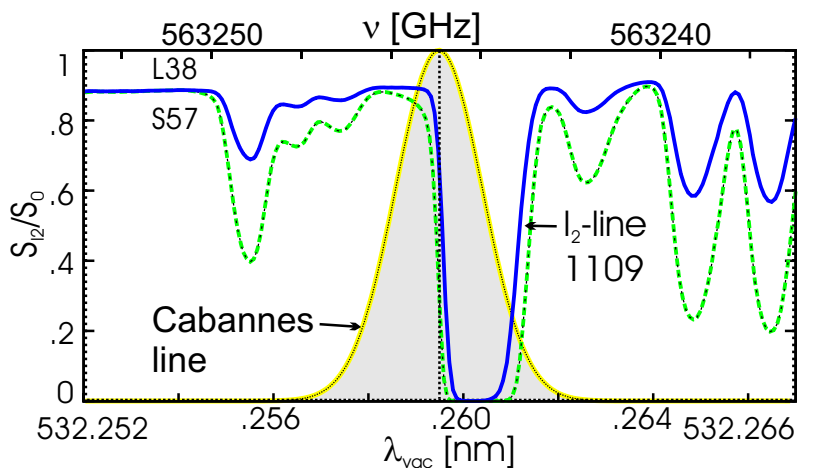

Fig. 2. Measured transmission spectrum of iodine for two cells of different length at different temperatures: $38^{\circ} \mathrm{C}$ (blue L38: $15 \mathrm{~cm}$ long), $57^{\circ} \mathrm{C}$ (green S57: $10 \mathrm{~cm}$ long). For reference, the Doppler broadened Cabannes line for $230 \mathrm{~K}$ is shown. The wavelength of the seed laser is indicated by a dotted vertical line.

trieval when using cell L38, as described in section 3. Over a period of three years the seed laser stability was better than $\Delta \lambda / \lambda=10^{-8}$ (Fiedler et al., 2008). As the system is designed to measure different atmospheric properties the lasers emit not only $532 \mathrm{~nm}$ radiation but also $1064 \mathrm{~nm}$ and $355 \mathrm{~nm}$. This reduces the output power at $532 \mathrm{~nm}$ (used for DoRIS) and reduces the efficiency of the optics involved. The two power lasers generate a peak power of about $50 \mathrm{MW}(14 \mathrm{~W}$ average) at $532 \mathrm{~nm}$ with a repetition rate of $30 \mathrm{~Hz}$ each. The pulse length is about $8 \mathrm{~ns}$, leading to a natural line broadening of about $20 \mathrm{MHz}$. For a similar laser type the pulse width was measured to be less than $70 \mathrm{MHz}$ (Fiedler and von Cossart, 1999). So we expect the actual pulse width to be less than $70 \mathrm{MHz}$ but not less than $20 \mathrm{MHz}$. To optimize the seeding process we use a seeding power of about $50 \mathrm{~mW}$ which is about 10 times higher than recommended by the manufacturer of the power lasers. Due to remaining imperfections in the seeding process (thermal perturbations etc.) the wavelength of the outgoing laser pulse can show an offset to the seed laser (Nicklaus et al., 2007). Therefore we measure the emitted wavelength during the atmospheric measurements with an $\mathrm{I}_{2}$ pulse spectrometer (Fiedler et al., 2008). The telescopes are independently tiltable from zenith pointing to $30^{\circ}$ off-zenith. One telescope (SET) can be tilted to the south-east quadrant, while the other one (NWT) can be tilted to the north-west quadrant. For wind measurements we use either $20^{\circ}$ or $30^{\circ}$ off-zenith tilt angle, depending on operational requirements e.g. measurements in a common volume with sounding rockets (Baumgarten et al., 2002).

To simplify the instrumental setup we use only one single polychromatic detection system by coupling the signal of the two telescopes/lasers alternatingly into the detection system. An overview of the detection system is shown in Fig. 4. The time multiplexed analysis of the backscattered light is performed by using a segmented mirror rotating at a frequency of $30 \mathrm{~Hz}$. The detection electronics itself is operated 


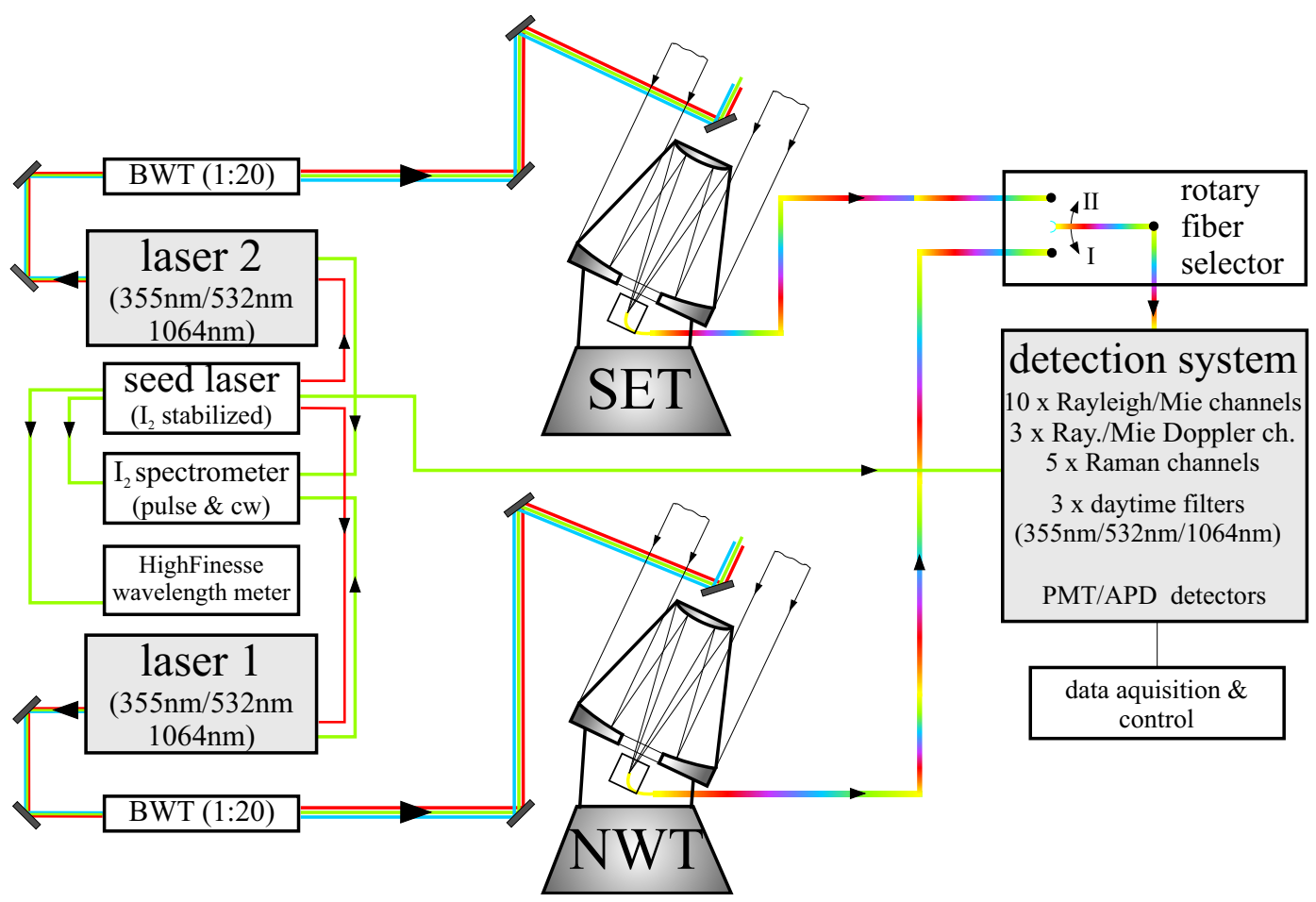

Fig. 3. Overview of the ALOMAR RMR lidar. Two pulsed power lasers (laser 1,2) are seeded with infrared light $(\lambda \sim 1064 \mathrm{~nm})$ by one cw-laser stabilized to iodine absorption line $1109(\lambda \sim 532 \mathrm{~nm})$. The optical connection between different components is indicated by red, green, and blue lines to indicate the wavelength of the light, $1064 \mathrm{~nm}, 532 \mathrm{~nm}, 355 \mathrm{~nm}$, respectively. The outgoing laser pulses are expanded to a diameter of $d=20 \mathrm{~cm}$ through beam widening telescopes (BWT) and guided to the optical axis of two tiltable telescopes $(d=1.8 \mathrm{~m})$. The light collected by the telescopes is guided through fibers $(d=1.5 \mathrm{~mm})$ to the detection system.

at a repetition frequency of $60 \mathrm{~Hz}$, while the lasers are firing alternatingly with $30 \mathrm{~Hz}$ each. Both lasers are synchronized to the chopper in the detection system. After separation of the wavelengths the $532 \mathrm{~nm}$ light is guided to the DoRIS spectrometer. We have optimized the spectrometer for stability by choosing an $\mathrm{I}_{2}$ cell with the most stable absorption spectrum. The $\mathrm{I}_{2}$ absorption was measured directly by scanning the $\mathrm{cw}$-seed laser. During the scan we measure the wavelength with a comecially available wavelength meter (HighFinesse WSU; "Highfinesse wavelength meter" in Fig. 3) with a precision of better than $10 \mathrm{MHz}$ over one hour. To calibrate the absolute wavelength we use the iodine atlas (Gerstenkorn and Luc, 1978). We found that a cell where $\mathrm{I}_{2}$ is completely in the gas phase (L38 in Fig. 2) gives the best stability. We analyzed the temperature dependence of different cells and found that the spectrometer drift is $36 \mathrm{MHz} / \mathrm{K}$ $(\sim 0.03 \mathrm{pm} / \mathrm{K})$ for cells with some $\mathrm{I}_{2}$ remaining in the bulk phase (S57 in Fig. 2), due to varying $I_{2}$ vapor pressure. For the saturated cells the drift due to Doppler broadening of the $\mathrm{I}_{2}$-line is only $0.7 \mathrm{MHz} / \mathrm{K}$. This frequency shift corresponds to a wind speed of about $0.18 \mathrm{~m} / \mathrm{s} / \mathrm{K}$.

The bandwidth of the $532 \mathrm{~nm}$ detection branch is $130 \mathrm{pm}$ during nighttime using a single interference filter and about $4 \mathrm{pm}$ during day using a double etalon system to reduce the solar background. Details about the double etalon system can be found in von Zahn et al. (2000). In DoRIS about $60 \%$ of the light is sent through the $\mathrm{I}_{2}$ cell. Due to the absorption in the $I_{2}$ this fraction results in about equal signal levels before and behind the cell. The beam diameter at the $\mathrm{I}_{2}$ cell is $36 \mathrm{~mm}$ and we use a cell with a diameter of $50 \mathrm{~mm}$ and a length of $150 \mathrm{~mm}$. The temperature is stabilized to better than $0.03 \mathrm{~K}$ at about $38^{\circ} \mathrm{C}$. The channel group before the $\mathrm{I}_{2}$ cell $\left(532 S_{0}\right)$ was used previously for high sensitivity study of NLC throughout the whole day (Fiedler et al., 2005). At the time DoRIS was integrated in the system we changed the detectors from photo multiplier tubes to more efficient avalanche photo diodes to compensate for the signal loss. In total six channels are used for DoRIS, three in front and three behind the cell. The channel groups are intensity cascaded with a splitting ratio of about 50 between high $(\mathrm{VH}$, VDH) and middle (VM, VDM) and middle (VM, VDM) and low (VL, VDL) altitude channels. To monitor the stability of DoRIS, light from the seeder is sent into the detection system about $1 \mathrm{~ms}$ after the start of each single laser pulse. For timing of the seeder light we use the same chopper that defines the timing of the power lasers. After passing the chopper the seeder light is sent through a coupler reproducing the angular intensity distribution from the telescopes and fed into the detection system through BS1 (Fig. 4) which has a reflectivity of higher than $99.99 \%$. The high reflectivity of BS1 


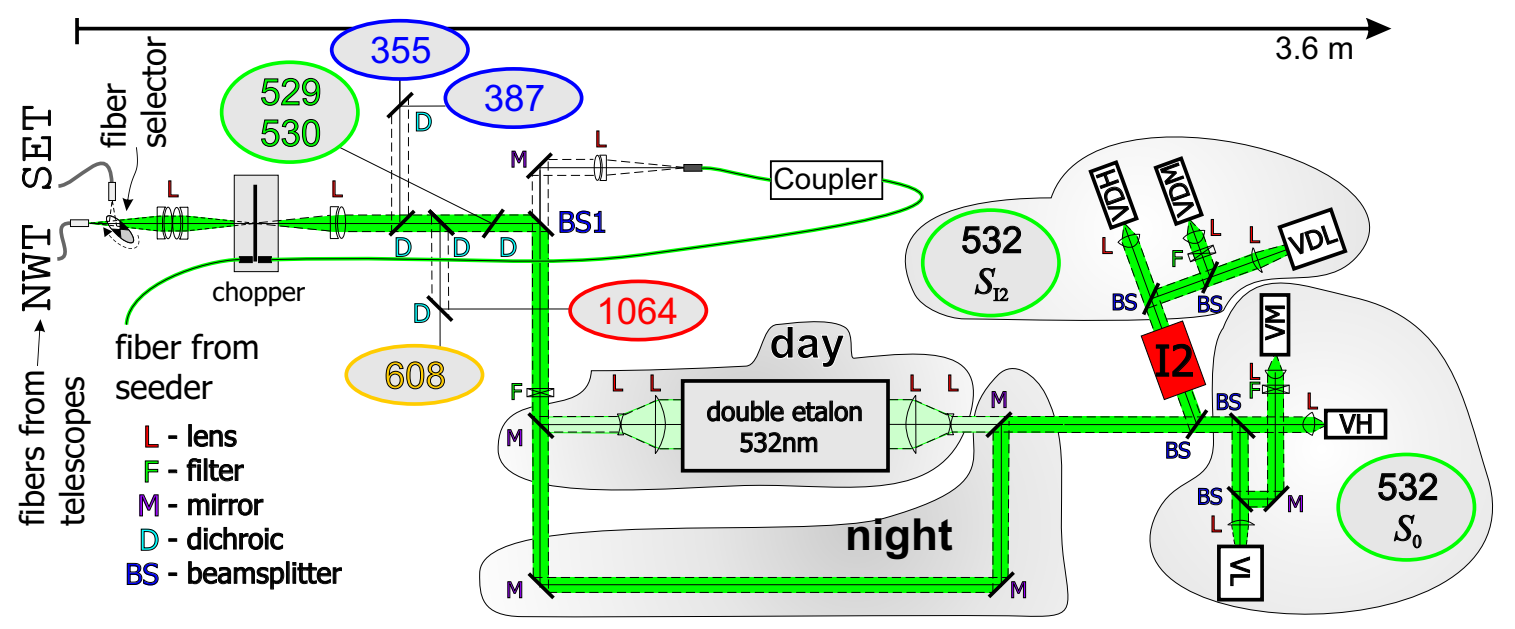

Fig. 4. Polychromatic detection system of the ALOMAR RMR lidar with emphasis on $532 \mathrm{~nm}$ channels. Light from the telescopes (NWT or SET) is split by wavelength and intensity. Light for the DoRIS system is detected by the channel groups $532-S_{0}$ and $532-S_{\mathrm{I}_{2}}$. The system can be operated during day using a double etalon system (bandpass $\sim 4 \mathrm{pm}$ ).

was chosen to minimize signal loss from the atmosphere and to attenuate the light from the seeder sufficiently, so it does not overload the high efficiency detectors. Mirrors, dichroics and beam splitters were optimized to have minimal polarization dependence. We repeatedly scanned the cell transmission spectrum using the seed laser in the last three years and could not detect any change. This indicates the stability of the DoRIS spectrometer.

\section{Data analysis}

The Doppler shift introduced by the movement of air along the line of sight is derived from the signal ratio behind and before the $\mathrm{I}_{2}$ cell: $D=S_{\mathrm{I}_{2}} / S_{0}$. This Doppler ratio $D$ is then compared to a modeled set, $D_{\text {model }}$, that was calculated by folding the measured $\mathrm{I}_{2}$ cell transmission spectrum and the Doppler broadened Cabannes line (Fig. 2). $D_{\text {model }}$ was calculated for line of sight wind speeds $(w)$ from $-200 \mathrm{~m} / \mathrm{s}$ to $200 \mathrm{~m} / \mathrm{s}$ and atmospheric temperatures $(T)$ from $130 \mathrm{~K}$ to $340 \mathrm{~K}$. The resulting table of $D_{\text {model }}$ is shown (color coded) in Fig. 5a. The seed wavelength was chosen to minimize the dependence of $D$ on temperature to only $\delta D / \delta T=1.8 \times 10^{-4} \mathrm{~K}^{-1}$ (Fig. $5 \mathrm{~b}$ ). The wind response is $\delta D / \delta w(w=0 \mathrm{~m} / \mathrm{s}, T=230 \mathrm{~K})=10^{-3} \mathrm{~m}^{-1}$ s, i.e. $1 \%$ per $10 \mathrm{~m} / \mathrm{s}$ (Fig. 5c). Although the temperature effect on $D$ is small we have to take it into account since the temperatures in the middle atmosphere can range from less than $150 \mathrm{~K}$ during summer to more than $320 \mathrm{~K}$ during stratospheric warmings (Lübken, 1999; von Zahn et al., 1998). Before calculating wind and temperature the two channel groups "VDH, VDM, VDL" and "VH, VM, VL" are combined to two profiles $S_{\mathrm{I}_{2}}$ and $S_{0}$, respectively (Fig. 6). The channels are combined by normalizing the lower altitude channels to $\mathrm{VH}$ (or $\mathrm{VDH}$ ) in an overlapping height range of about $7 \mathrm{~km}$. The lower boundary of this overlapping height range is indicated with grey arrows in (Fig. 6). To estimate the measurement uncertainty we calculate the shot noise of the number of photons received and use Gaussian error propagation throughout the retrieval process. The temperature is calculated from $S_{0}$ by hydrostatic integration in the aerosol free part of the atmosphere, usually above $30 \mathrm{~km}$ (Hauchecorne and Chanin, 1980). This method has an accuracy of $1-2 \mathrm{~K}$ in the upper strato- and lower mesosphere (e.g. Keckhut et al., 1993; Leblanc et al., 1998; Randel et al., 2009). To calculate wind in the aerosol loaded part of the atmosphere the calculation of $D_{\text {model }}$ has to include the aerosol spectral signature. Either temperature measurements using the rotational Raman method ( $\lambda=529 \mathrm{~nm}$ and $\lambda=530 \mathrm{~nm}$ in Fig. 4) or from ECMWF (European Center for Medium range Weather Forecast) analysis will give sufficiently precise information to calculate the Doppler broadening of the Cabannes and aerosol line (e.g., Jumelet et al., 2009; Schöch et al., 2008). For the moment we only analyze data in the aerosol free part of the atmosphere. The information about the aerosol load is usually taken from the $1064 \mathrm{~nm}$ channel (aerosol and molecular scatter), compared to the $608 \mathrm{~nm}$ signal that is generated only from scattering on $\mathrm{N}_{2}$ molecules.

In the analysis of winds there are two system parameters that are changing with time but need to be known precisely. One is the wavelength offset $\left(\Delta \lambda_{0}\right)$ between the power lasers and the seed laser. The other is the signal ratio $\left(D_{0}\right)$ of the two channel groups $S_{\mathrm{I}_{2}}$ and $S_{0}$ at the seed wavelength due to varying quantum efficiency of the detectors. Both parameters are measured during operation. From calibration measurements we know that $D_{0}$ also depends on the way that the light is feed into the detection system. During calibration we measure $D_{0}$ for all entrances (both telescopes and the seeder entrance) simultaneously. During operation we only measure $D_{0}$ for the seeder entrance $\left(D_{\text {seeder }}\right)$ but take the ratio 


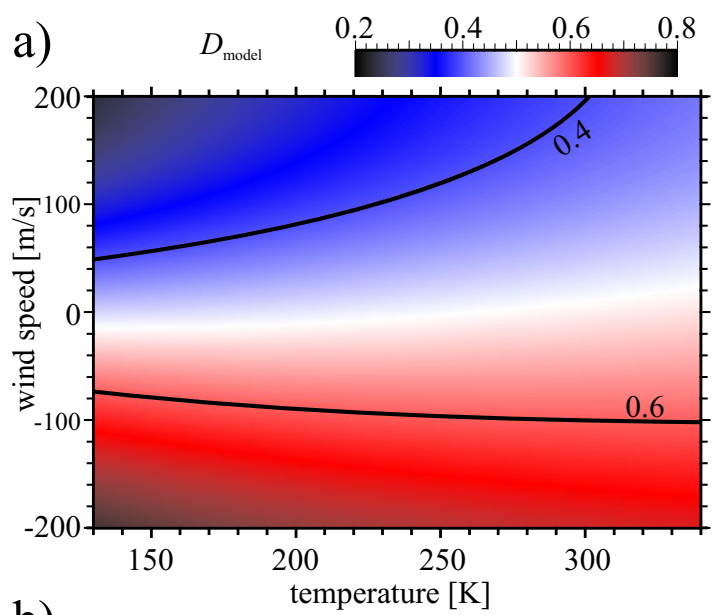

b)

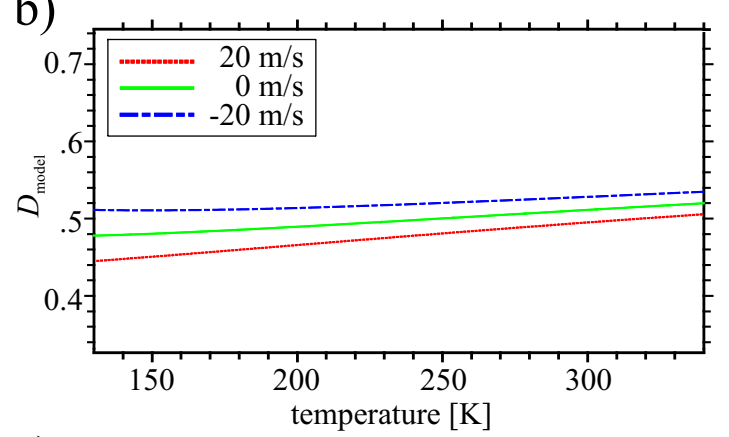

c)

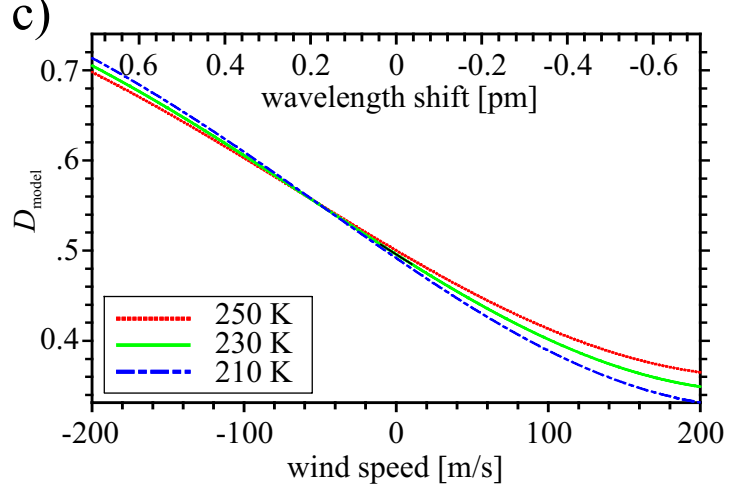

Fig. 5. Modeled Doppler ratio $D_{\text {model }}$ for different combinations of temperature and wind speed. (a) Color coded atmospheric temperature and wind response with isolines of $D_{\text {model }}=0.4$ and $D_{\text {model }}=0.6$. (b) Temperature response for $0,+20,-20 \mathrm{~m} / \mathrm{s}$ wind speed. (c) Wind response for atmospheric temperatures of 210, 230, $250 \mathrm{~K}$.

between the seeder entrance and the telescope entrances into account when deriving Doppler winds. We found for the north-west telescope $D_{0}=D_{\mathrm{NWT}}=0.9917 \cdot D_{\text {seeder }}$ and for the south-east telescope $D_{0}=D_{\mathrm{SET}}=0.8776 \cdot D_{\text {seeder }}$. This system parameter depends on the alignment of the system and basically describes the overlap of the different entrances imaged at the detector and the detector area. The parameter remains constant unless the alignment of the detection system is changed. For the actual wind retrieval the lookup

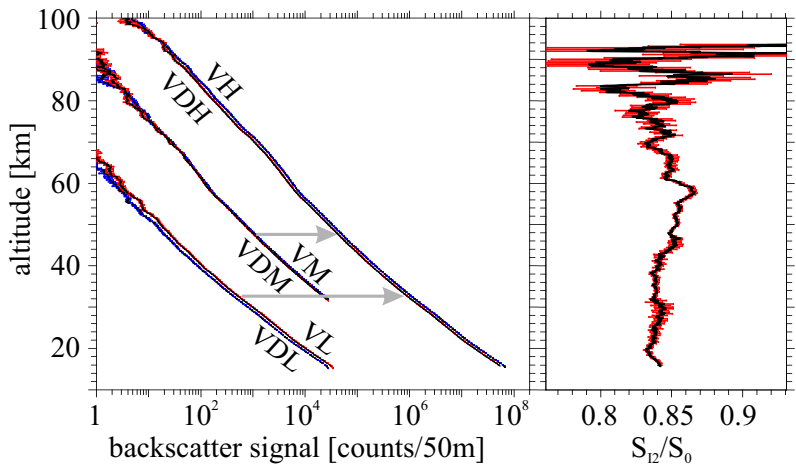

Fig. 6. Left: Backscatter profile of the vertical pointing telescope on 17 January 2009 from 17:00 to 19:00 UT. Data of the channel groups "VDH, VDM, VDL" (black/blue) and "VH, VM, VL" (black/red) is combined to two profiles $S_{\mathrm{I}_{2}}$ and $S_{0}$, respectively. The measurement uncertainty $(1 \sigma)$ is indicated by red or blue horizontal bars. Grey arrows indicate the altitude where the channels were combined. Right: Measured Doppler ratio $D=S_{\mathrm{I}_{2}} / S_{0}$ and the corresponding error bars (red).

table $D_{\text {model }}(T, w)$ is restricted to the measured temperature $T(z)$ at the altitude $z$ and then the line of sight wind $w(z)$ is retrieved by finding $D_{\text {model }}(T=T(z), w(z))=D(z) / D_{0}$. Finally the wind offset due to the wavelength offset $\left(\Delta \lambda_{0}\right)$ is subtracted.

\section{Initial observations}

We have performed a number of DoRIS wind and calibration measurements during January 2009 and we show data from two days (17 and 23 January) analyzed so far. On both days we have integrated the profiles for two hours, centered around 18:00 UT. At 18:00 UT data from the ECMWF is available and can be used for comparison to the actual measurements. We use ECMWF analysis data extracted on pressure levels from ground to about $62 \mathrm{~km}$ altitude. As the frequency offset between seeder and power laser is crucial for absolute wind retrieval we show the histogram of Laser pulse frequency offset in Fig. 7. During these two observations the mean wavelength offsets of the power lasers to the seed laser $\left(\Delta \lambda_{0}\right)$ were $-13.0 \mathrm{MHz}$ and $-11.5 \mathrm{MHz}$ for laser 1 and $-13.7 \mathrm{MHz}$ and $-14.3 \mathrm{MHz}$ for laser 2. The distribution width ranges from $6.5 \mathrm{MHz}$ to $17.5 \mathrm{MHz}$. The error of the mean is $0.09 \mathrm{MHz}$ to $0.24 \mathrm{MHz}$. As the mean offset is taken into account during the wind retrieval the error of the mean results in a systematic error of the retrieved wind of about $0.05 \mathrm{~m} / \mathrm{s}$. To investigate the aerosol free altitude range we show the aerosol load in Fig. 8. The aerosol load is described by the backscatter ratio $R=\left(\beta_{\mathrm{a}}+\beta_{\mathrm{m}}\right) / \beta_{\mathrm{m}}$. Here $\beta_{\mathrm{a}}$ and $\beta_{\mathrm{m}}$ are the backscatter coefficients for aerosols and molecules, respectively. One can see that the top of the aerosol layer varies by more than $10 \mathrm{~km}$ within a few days. This is due to the high latitude of the ALOMAR research 


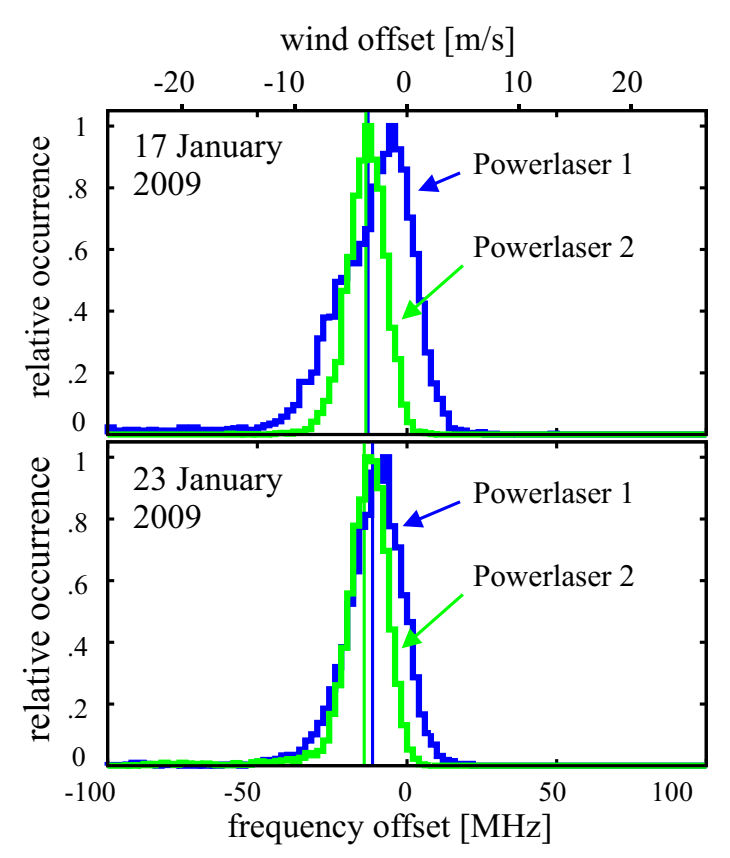

Fig. 7. Histogram of pulsed laser frequency offset to seed laser during the measurements on 17 January 2009 (upper pannel) and 23 February 2009 (lower pannel). The mean values are indicated by vertical bars. The apparent wind offset is indicated in the upper scale. The mean apparent wind offset is taken into account when deriving the actual wind profile.

station where the stratospheric aerosol layer is affected by the polar vortex dynamics (e.g., McCormick et al., 1983; Kent et al., 1985). From the aerosol profiles we realize that on 17 January ALOMAR was located outside the polar vortex, while on 23 January ALOMAR was sounding under the vortex. On 17 January 2009 the NWT was pointing north, $30^{\circ}$ off-zenith and the SET was pointing to zenith. Laser 1 was assigned to the NWT and laser 2 to the SET. This pointing was chosen for joint observations with a sounding rocket launched from the Andøya Rocket range during the Delta 2 campaign (e.g., Williams et al., 2006).

In Fig. 6 we show the backscatter profiles (background subtracted) accumulated during two hours of measurements, centered at 18:00 UT on 17 January 2009. The data was acquired with the vertical pointing south-east telescope and laser 2 . We have smoothed the data with a $2 \mathrm{~km}$ running mean filter. The Doppler ratio calculated from the combination of the channel groups is varying only slightly with altitude. This indicates that the vertical wind is small and not changing systematically with altitude. The variations of the Doppler ratio with altitude are mainly induced by changes in the atmospheric temperature. This becomes more clear when comparing the Doppler ratio with the temperature deduced from hydrostatic integration. The retrieved temperature and wind components are shown in Fig. 9. The temperature profile is calculated by averaging the measurements of both tele-

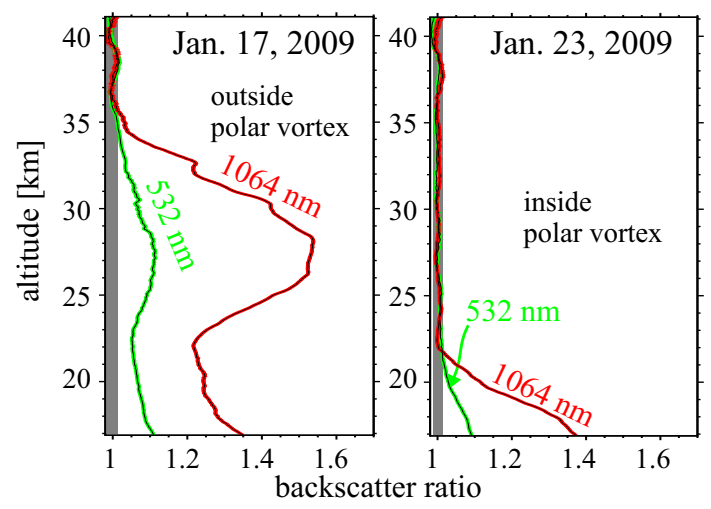

Fig. 8. Aerosol backscatter ratio during the measurements on 17 and 23 January 2009. The gray vertical bar indicates the aerosol free signal $\pm 1 \%$. The measurement uncertainty is indicated by the thickness of the green and red lines. The aerosol contribution to the signal was less than $1 \%$ at $532 \mathrm{~nm}$ for altitudes above $34 \mathrm{~km}$ and $22 \mathrm{~km}$ on 17 and 23 January, respectively. The data is smoothed using a running mean of about $2 \mathrm{~km}$. A recent description of the analysis method can be found in Jumelet et al. (2009).

scopes. We find the maximum temperature of about $275 \mathrm{~K}$ at an altitude of $58 \mathrm{~km}$. At the same altitude the Doppler ratio in Fig. 6 reaches its maximum. During the measurement the atmosphere was disturbed by a developing major stratospheric warming occurring on 24 January 2009 (Labitzke and Kunze, 2009; Manney et al., 2009). We observe a strong wave disturbance in the temperature profile from about 55 to $75 \mathrm{~km}$. From about $58 \mathrm{~km}$ to $70 \mathrm{~km}$ we observe a quasi adiabatic lapse rate similar to the thermal structure under summer conditions. The stratospheric warming can be seen in the disturbed temperature profile and especially in the unusual meridional wind profile. Under typical winter conditions the meridional wind is much lower and shows no upper stratospheric southward directed jet. We pointed one telescope to zenith to investigate the quality of the system as the $2 \mathrm{~h}$ average vertical winds should be below our detection threshold. The vertical wind profile in Fig. 9 shows that the vertical wind profile is constant with altitude and shows no extreme values at $58 \mathrm{~km}$ altitude, where we observed the highest temperatures. The resulting nearly zero vertical wind, although the measured channel ratio was not constant with altitude, demonstrates that the temperature effect (Doppler broadening) is correctly treated in the wind retrieval. The meridional wind in Fig. 9 agrees with the ECMWF analysis taking the coarser altitude resolution of the model into account.

In Fig. 9 we also show results from the SKiYMET meteor radar averaged from 17:00 to 19:00 UT. We find that at the top of the altitude range covered by the lidar the meridional wind agrees well with the wind derived from the collocated radar instrument. The statistical uncertainty of the line of sight wind is $9 \mathrm{~m} / \mathrm{s}$ and $19 \mathrm{~m} / \mathrm{s}$ for the horizontal wind at $80 \mathrm{~km}$. The gray area in Fig. 9 indicates aerosol loaded altitudes where more than $1 \%$ of the signal of the $532 \mathrm{~nm}$ 


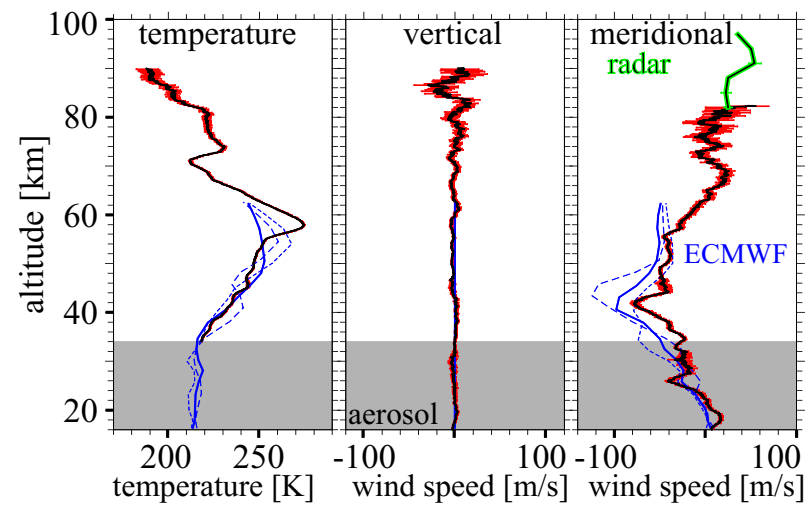

Fig. 9. Temperature, vertical and meridional wind on 17 January 2009 between 17:00 and 19:00 UT. ECMWF data from 18:00 UT (solid) and 12:00, 24:00 UT (dashed) are shown. Simultaneous observations by the collocated Meteor radar are shown. The gray area indicates altitudes with aerosol contribution as measured by the lidar.

channel or $10 \%$ of the signal of the $1064 \mathrm{~nm}$ channel are scattered from aerosol particles. Retrieved winds in these altitudes could be biased as we do not take aerosol contributions into account yet.

On 23 January 2009 the NWT and SET were pointing $20^{\circ}$ off-zenith to north and east, respectively. Figure 10 shows temperature and both components of the horizontal wind measured from 17:00 to 19:00 UT. We again observe a good agreement of the structure with the ECMWF wind and excellent agreement of lidar and radar winds at the top of the lidar profile. It should be noted that large temperature offsets of ECMWF temperatures and observed temperatures similar to the differences shown in Figs. 9 and 10 of about $10 \mathrm{~K}$ to $30 \mathrm{~K}$ have been reported earlier (Schöch et al., 2008). At altitudes above $30 \mathrm{~km}$ deviations of about $25 \mathrm{~K}$ have been observed for observations on scales of a few hours. These large differences occur especially during stratospheric warmings. At the same time the mean deviations on monthly scales are about $3 \mathrm{~K}$ and less. As there is no systematic investigation of wind observations and ECMWF winds at around the stratopause available yet, we find our agreement between lidar and ECMWF already noteworthy and remaining differences will be investigated in future. We observe remarkable changes in the thermal and dynamical structure of the atmosphere as the stratospheric warming evolves. This is partly caused by the location of the polar vortex which changed from 17 to 23 January.

From the ECMWF data in Fig. 11 one can see that ALOMAR is sounding low latitude air masses with high ozone values on 17 January, while there were polar air masses above ALOMAR with low ozone at $25 \mathrm{~km}$ on 23 January. This is in excellent agreement with the aerosol observations that indicated that ALOMAR is outside the vortex on 17 January but inside on 23 January. On 23 January the vortex is

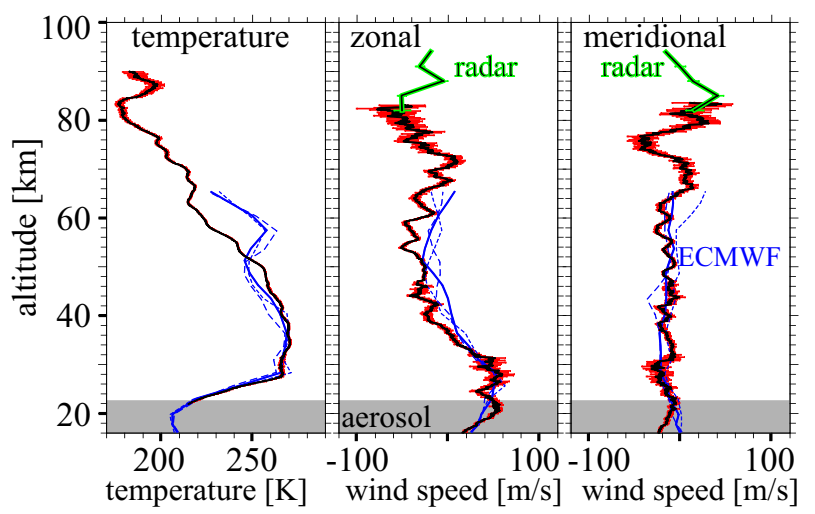

Fig. 10. Temperature and horizontal wind on 23 January 2009 between 17:00 and 19:00 UT. More details in Fig. 9.

almost split which can be seen in Fig. 11. The figure shows that ECMWF horizontal wind speeds are larger than $120 \mathrm{~m} / \mathrm{s}$ and up to $200 \mathrm{~m} / \mathrm{s}$ in the upper stratosphere. The DoRIS wind precision of better than $20 \mathrm{~m} / \mathrm{s}$ up to $80 \mathrm{~km}$ is well suited to measure such wind speeds, especially at the stratopause where the precision for lidar wind soundings is about 1 to $3 \mathrm{~m} / \mathrm{s}$. Under daylight conditions the top altitude for temperature soundings decreases by about $20 \mathrm{~km}$. At the same time the MF radar wind observations reach lower down under sunlight conditions, hence the combination of lidar and radar winds will allow for continuous wind soundings throughout the strato- and mesosphere.

\section{Conclusions}

The ALOMAR RMR lidar was successfully enhanced to perform Doppler wind measurements throughout the strato- and mesosphere without interrupting the long-term observation of temperature and aerosols in the middle atmosphere. The lidar can perform temperature and horizontal wind measurements between about $30 \mathrm{~km}$ and $80 \mathrm{~km}$. Using the simultaneously measured aerosol contribution we expect to extend the measurement range. The frequecy of the outgoing laser pulses as well as the relative sensitivity of the detectors is recorded throughout the atmospheric measurement and included in the retrieval. Currently the accuracy of the wind measurement is dominated by the (random) error of the atmospheric signal; Hence the minimum measurement uncertainty of the line of sight wind for $2 \mathrm{~km}$ range resolution and $2 \mathrm{~h}$ time resolution is $0.6 \mathrm{~m} / \mathrm{s}$ at about $49 \mathrm{~km}$ altitude. At an altitude of $80 \mathrm{~km}$ the uncertainty of the line of sight wind increases to about $10 \mathrm{~m} / \mathrm{s}$, resulting in an uncertainty of the horizontal wind of $20 \mathrm{~m} / \mathrm{s}$. The fidelity of DoRIS was proven by vertical wind measurements and comparison to independent radar wind measurements. For future analysis we will include aerosol effects especially to deduce wind in noctilucent clouds $(\sim 83 \mathrm{~km})$ which provide a strong signal. This 


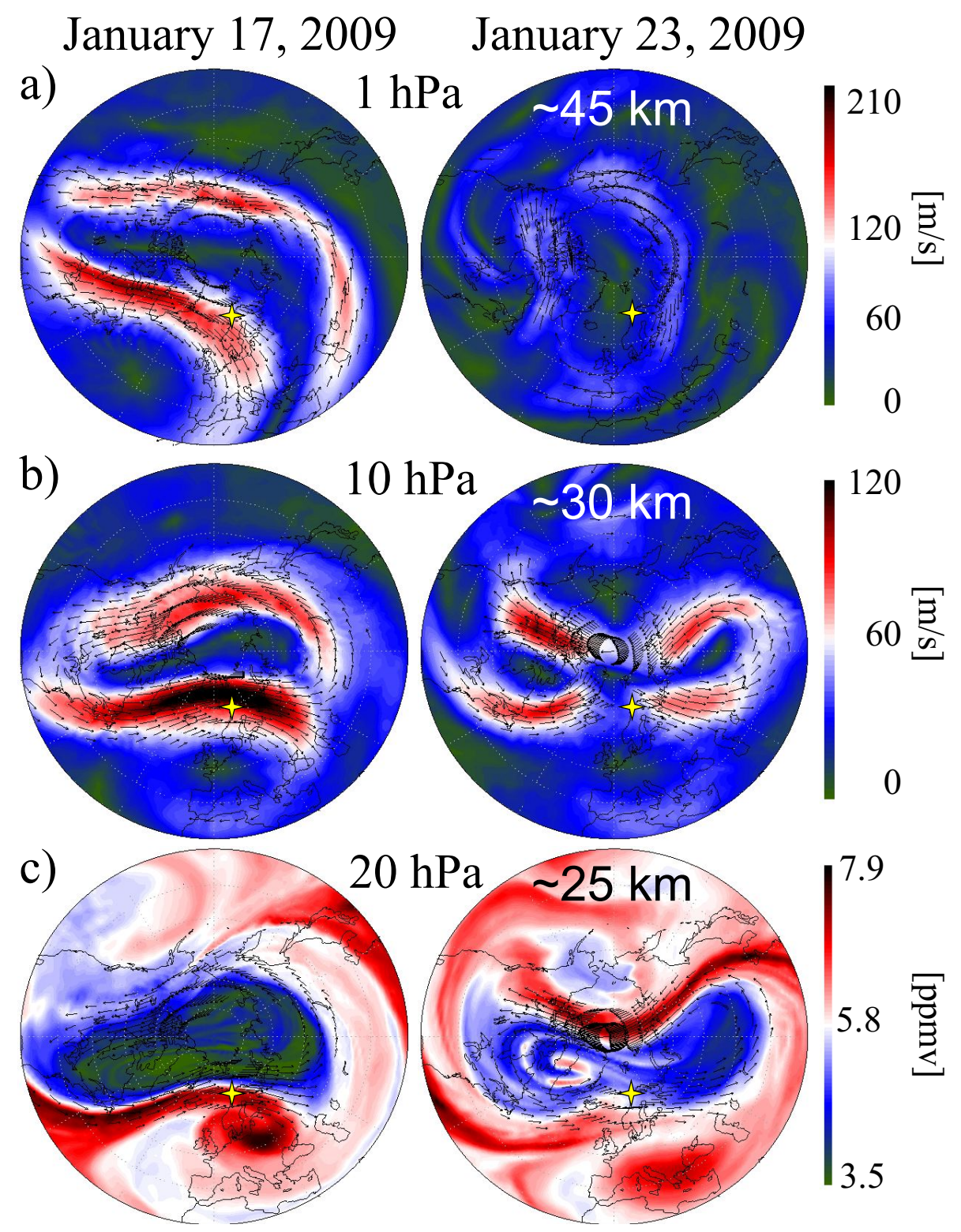

Fig. 11. Horizontal wind and ozone concentration on different levels on 17 January and 23 January 2009 18:00 UT extracted from ECMWF (European Center for Medium range Weather Forecast) operational analysis. (a) Horizontal wind at $1 \mathrm{hPa}$ level ( $\sim 45 \mathrm{~km})$. (b) Horizontal wind at $10 \mathrm{hPa}$ level $(\sim 30 \mathrm{~km})$. (c) Ozone (color contour) and horizontal wind (vectors) at $20 \mathrm{hPa}$ level $(\sim 25 \mathrm{~km})$. Wind vectors are only plotted for wind speeds larger than $40 \mathrm{~m} / \mathrm{s}$. Please note that the color scale is changing for the different pressure levels. The location of ALOMAR is indicated by a yellow star. Greenwich Meridian is found at the bottom of the plots.

new method for wind measurements improves previous lidar Rayleigh Doppler wind measurements at ALOMAR that did not reach above $30 \mathrm{~km}$ on regular basis (Baumgarten et al., 1999). Under favorable conditions the comparison to other wind measurements performed at the ALOMAR research station will be possible. For example the MF radar can provide wind informations down to $\sim 70 \mathrm{~km}$. Data combination with the sodium resonance lidar at ALOMAR might be possible with the benefit that both instruments use the same sounding volume.
Acknowledgements. The work benefited from the excellent support by J. Fiedler, K. H. Fricke, J. Hildebrand, J. Höffner, P. Hoffmann, T. Köpnick, F.-J. Lübken, G. von Cossart, and the dedicated staff at the ALOMAR observatory. Data provided by the radar department at the IAP allowed for confirmation of lidar measurements. The European Centre for Medium-Range Weather Forecasts (ECMWF) is gratefully acknowledged for providing the operational analysis data. This project is supported by DFG (Deutsche Forschungsgemeinschaft BA 2834/1-1).

Edited by: G. Ehret 


\section{References}

Abreu, V. J., Barnes, J. E., and Hays, P. B.: Observations of winds with an incoherent lidar detector, Appl. Optics, 31, 4509-4514, doi:10.1364/AO.31.004509, 1992.

Baumgarten, G. and Fiedler, J.: Vertical structure of particle properties and water content in noctilucent clouds, Geophys. Res. Lett., 35, L10811, doi:10.1029/2007GL033084, 2008.

Baumgarten, G., Rees, D., and Lloyd, N. D.: Observations of Arctic Stratospheric Winds by the ALOMAR Doppler Wind and Temperature System, Proc. 14th ESA Symposium on European Rocket and Balloon Programmes and Related Research, edited by: Kaldeich-Schürmann, B., ESA SP-437, 331-334, 1999.

Baumgarten, G., Lübken, F.-J., and Fricke, K. H.: First observation of one noctilucent cloud by a twin lidar in two different directions, Ann. Geophys., 20, 1863-1868, doi:10.5194/angeo20-1863-2002, 2002.

Chanin, M. L., Garnier, A., Hauchecorne, A., and Porteneuve, J.: A Doppler lidar for measuring winds in the middle atmosphere, Geophys. Res. Lett., 16, 1273-1276, doi:10.1029/GL016i011p01273, 1989.

Fiedler, J. and von Cossart, G.: Automated lidar transmistter for multiparameter investigations within the Arctic atmosphere, IEEE T. Geosci. Remote, 37, 748-755, doi:10.1109/36.210442, 1999.

Fiedler, J., Baumgarten, G., and von Cossart, G.: Mean diurnal variations of noctilucent clouds during 7 years of lidar observations at ALOMAR, Ann. Geophys., 23, 1175-1181, doi:10.5194/angeo-23-1175-2005, 2005.

Fiedler, J., Baumgarten, G., and von Cossart, G.: A middle atmosphere lidar for multi-parameter measurements at a remote site, in: Papers presented at the 24th ILRC, 824-827, 2008.

Fiedler, J., Baumgarten, G., and Lübken, F.-J.: NLC observations during one solar cycle above ALOMAR, J. Atmos. Sol.-Terr. Phys., 71, 424-433, doi:10.1016/j.jastp.2008.11.010, 2009.

Friedman, J. S., Tepley, C. A., Castleberg, P. A., and Roe, H.: Middle-atmospheric Doppler lidar using an iodine-vapor edge filter, Opt. Lett., 22, 1648-1650, doi:10.1364/OL.22.001648, 1997.

Garnier, A. and Chanin, M. L.: Description of a Doppler Rayleigh LIDAR for measuring winds in the middle atmosphere, Appl. Phys. B, 55, 35-40, doi:10.1007/BF00348610, 1992.

Gentry, B. M., Chen, H., and Li, S. X.: Wind measurements with 355-nm molecular Doppler lidar, Opt. Lett., 25, 1231-1233, doi:10.1364/OL.25.001231, 2000.

Gerstenkorn, S. and Luc, P.: Atlas du spectre d'absorption de la molecule d'iode, in: Edition du CNRS, Paris, 1978.

Goldberg, R. A., Fritts, D. C., Williams, B. P., Lübken, F.-J., Rapp, M., Singer, W., Latteck, R., Hoffmann, P., Müllemann, A., Baumgarten, G., Schmidlin, F. J., She, C., and Krueger, D. A.: The MaCWAVE/MIDAS rocket and groundbased measurements of polar summer dynamics: Overview and mean state structure, Geophys. Res. Lett., 31, L24S02, doi:10.1029/2004GL019411, 2004.

Hauchecorne, A. and Chanin, M.: Density and temperature profiles obtained by lidar between 35 and $70 \mathrm{~km}$, GRL, 7, 565-568, doi:10.1029/GL007i008p00565, 1980.

Huang, W., Chu, X., Williams, B. P., Harrell, S. D., Wiig, J., and She, C.-Y.: Na double-edge magneto-optic filter for Na lidar profiling of wind and temperature in the lower atmosphere, Opt.
Lett., 34, 199-201, doi:10.1364/OL.34.000199, 2009.

Jumelet, J., Bekki, S., David, C., Keckhut, P., and Baumgarten, G.: Size distribution time series of a polar stratospheric cloud observed above Arctic Lidar Observatory for Middle Atmosphere Research (ALOMAR) $\left(69^{\circ} \mathrm{N}\right)$ and analyzed from multiwavelength lidar measurements during winter 2005, J. Geophys. Res., 114, D02202, doi:10.1029/2008JD010119, 2009.

Keckhut, P., Hauchecorne, A., and Chanin, M. L.: A Critical Review of the Database Acquired for the Long-Term Surveillance of the Middle Atmosphere by the French Rayleigh Lidars, J. Atmos. Ocean. Techn., 10, 850-867, doi:10.1175/15200426(1993)010<0850:ACROTD>2.0.CO;2, 1993.

Kent, G. S., Farrukh, U. O., Trepte, C. R., and McCormick, M. P.: Variation in the stratospheric aerosol associated with the North Cyclonic Polar Vortex as measured by the SAM II satellite sensor, J. Atmos. Sci., 42, 1536-1551, doi:10.1175/15200469(1985)042<1536:VITSAA > 2.0.CO;2, 1985.

Labitzke, K. and Kunze, M.: On the remarkable Arctic winter in 2008/2009, J. Geophys. Res., 114, D00I02, doi:10.1029/2009JD012273, 2009.

Latteck, R., Singer, W., and Bardey, H.: The ALWIN MST Radar: Technical Design and Performance, Proc. 14th ESA Symposium on European Rocket and Balloon Programmes and Related Research, edited by: Kaldeich-Schürmann, B., ESA SP-437, 179184, 1999.

Leblanc, T., McDermid, I. S., Hauchecorne, A., and Keckhut, P.: Evaluation of optimization of lidar temperature analysis algorithms using simulated data, J. Geophys. Res., 103, 6177-6188, doi:10.1029/97JD03494, 1998.

Liu, Z., Wu, D., Liu, J., Zhang, K., Chen, W., Song, X., Hair, J. W., and She, C.: Low-altitude atmospheric wind measurement from the combined Mie and Rayleigh backscattering by Doppler lidar with an iodine filter, Appl. Optics, 41, 7079-7086, doi:10.1364/AO.41.007079, 2002.

Liu, Z. S., Chen, W. B., Zhang, T. L., Hair, J. W., and She, C. Y.: An incoherent Doppler lidar for ground-based atmospheric wind profiling, Appl. Phys. B, 64, 561-566, doi:10.1007/s003400050215, 1997.

Liu, Z. S., Liu, B. Y., Li, Z. G., Yan, Z. A., Wu, S. H., and Sun, Z. B.: Wind measurements with incoherent Doppler lidar based on iodine filters at night and day, Appl. Phys. B, 88, 327-335, doi:10.1007/s00340-007-2674-y, 2007.

Lübken, F.-J.: Thermal structure of the Arctic summer mesosphere, J. Geophys. Res., 104, 9135-9149, doi:10.1029/1999JD900076, 1999.

Manney, G. L., Schwartz, M. J., Krüger, K., Santee, M. L., Pawson, S., Lee, J. N., Daffer, W. H., Fuller, R. A., and Livesey, N. J.: Aura Microwave Limb Sounder observations of dynamics and transport during the record-breaking 2009 Arctic stratospheric major warming, Geophys. Res. Lett., 36, L12815, doi:10.1029/2009GL038586, 2009.

McCormick, M. P., Trepte, C. R., and Kent, G. S.: Spatial changes in the stratospheric aerosol associated with the north polar vortex, Geophys. Res. Lett., 10, 941-944, doi:10.1029/GL010i010p00941, 1983.

Meriwether, J. W. and Gerrard, A. J.: Mesosphere inversion layers and stratosphere temperature enhancements, Rev. Geophys., 42, RG3003, doi:10.1029/2003RG000133, 2004.

Müllemann, A. and Lübken, F.-J.: Horizontal winds in the meso- 
sphere at high latitudes, Adv. Space Res., 35, 1890-1894, doi:10.1016/j.asr.2004.11.014, 2005.

Nicklaus, K., Morasch, V., Höfer, M., Luttmann, J., Vierkoetter, M., Ostermeyer, M., Höffner, J., Lemmerz, C., and Hoffmann, D.: Frequency stabilization of Q-switched Nd:YAG oscillators for airborne and spaceborne LIDAR systems, in: Proceedings of SPIE, vol. 6451, doi:10.1117/12.701187, 2007.

Randel, W. J., Shine, K. P., Austin, J., Barnett, J., Claud, C., Gillett, N. P., Keckhut, P., Langematz, U., Lin, R., Long, C., Mears, C., Miller, A., Nash, J., Seidel, D. J., Thompson, D. W. J., Wu, F., and Yoden, S.: An update of observed stratospheric temperature trends, J. Geophys. Res., 114, D02107, doi:10.1029/2008JD010421, 2009.

Rees, D. and McDermid, I. S.: Doppler lidar atmospheric wind sensor - Reevaluation of a 355-nm incoherent Doppler lidar, Appl. Optics, 29, 4133-4144, doi:10.1364/AO.29.004133, 1990.

Rees, D., Vyssogorets, M., Meredith, N. P., Griffin, E., and Chaxell, Y.: The Doppler Wind and Temperature System of the ALOMAR Lidar facility: overview and initial results, J. Atmos. Sol.Terr. Phys., 58, 1827-1842, doi:10.1016/0021-9169(95)00174-3, 1996.

Schöch, A., Baumgarten, G., and Fiedler, J.: Polar middle atmosphere temperature climatology from Rayleigh lidar measurements at ALOMAR ( $\left.69^{\circ} \mathrm{N}\right)$, Ann. Geophys., 26, 1681-1698, doi:10.5194/angeo-26-1681-2008, 2008.

She, C.-Y., Yue, J., Yan, Z.-A., Hair, J. W., Guo, J.-J., Wu, S.H., and Liu, Z.-S.: Direct-detection Doppler wind measurements with a Cabannes Mie lidar: A. Comparison between iodine vapor filter and Fabry Perot interferometer methods, Appl. Optics, 46, 4434-4443, doi:10.1364/AO.46.004434, 2007.

Singer, W., Keuer, D., and Eriksen, W.: The ALOMAR MF radar: Technical design and first results, Proc. 13th ESA Symposium on European Rocket and Balloon Programmes and Related Research, edited by: Kaldeich-Schürmann, B., ESA SP-397, 101103, 1997.

Singer, W., Bremer, J., Hocking, W. K., Weiss, J., Latteck, R., and Zecha, M.: Temperature and wind tides around the summer mesopause at middle and Arctic latitudes, Adv. Space Res., 31, 2055-2060, doi:10.1016/S0273-1177(03)00228-X, 2003.
Souprayen, C., Garnier, A., Hertzog, A., Hauchecorne, A., and Porteneuve, J.: Rayleigh-Mie Doppler wind lidar for atmospheric measurements. I. Instrumental setup, validation, and first climatological results, Appl. Optics, 38, 2410-2421, doi:10.1364/AO.38.002410, 1999.

Tepley, C. A.: Neutral winds of the middle atmosphere observed at Arecibo using a Doppler Rayleigh lidar, J. Geophys. Res., 99, 25781-25790, doi:10.1029/94JD02213, 1994.

Tepley, C. A., Sargoichev, S. I., and Hines, C. O.: Initial Doppler Rayleigh lidar results from Arecibo, Geophys. Res. Lett., 18, 167-170, doi:10.1029/90GL02670, 1991.

Tepley, C. A., Sargoytchev, S. I., and Rojas, R.: The Doppler Rayleigh lidar system at Arecibo, IEEE T. Geosci. Remote, 31, 36-47, doi:10.1109/36.210442, 1993.

von Zahn, U., Fiedler, J., Naujokat, B., Langematz, U., and Krüger, K.: A note on record-high temperatures at the northern polar stratopause in winter 1997/98, Geophys. Res. Lett., 25, 41694172, doi:10.1029/1998GL900091, 1998.

von Zahn, U., von Cossart, G., Fiedler, J., Fricke, K. H., Nelke, G., Baumgarten, G., Rees, D., Hauchecorne, A., and Adolfsen, K.: The ALOMAR Rayleigh/Mie/Raman lidar: Objectives, configuration, and performance, Ann. Geophys., 18, 815-833, doi:10.1007/s00585-000-0815-2, 2000.

Williams, B. P., Fritts, D. C., Wang, L., She, C. Y., Vance, J. D., Schmidlin, F. J., Goldberg, R. A., Müllemann, A., and Lübken, F.-J.: Gravity waves in the Arctic mesosphere during the MaCWAVE/MIDAS summer rocket program, Geophys. Res. Lett., 31, L24S05, doi:10.1029/2004GL020049, 2004.

Williams, B. P., Fritts, D. C., Vance, J. D., She, C., Abe, T., and Thrane, E.: Sodium lidar measurements of waves and instabilities near the mesopause during the DELTA rocket campaign, Earth Planets Space, 58, 1131-1137, 2006.

Young, A. T.: Rayleigh scattering, Appl. Optics, 20, 533-535, doi:10.1364/AO.20.000533, 1981. 